Jolanta Kolbuszewska (Łódź)

iD https://orcid.org/0000-0002-8837-7376

\title{
Halina Evert-Kappesowa, (Co-)Founder of Post-War Polish Byzantine Studies
}

\section{Biography}

he historian that laid the foundation for post-war Polish Byzantine research
- Halina Janina Evert-Kappesowa - came from a respected family within Polish culture and industry. Her father, Ludwik Józef Evert (1863-1945), a descendant of a French family that settled in Poland in the $18^{\text {th }}$ century, was a very welleducated man. He graduated from secondary school in Radom and the Leopold Kronenberg College of Commerce in Warsaw; later, he completed additional studies in Königsberg and Paris as well as professional practice in Germany. From 1887-1895, he managed textile companies and then became a representative of the Russian textile industry in Łódź. In 1896, he and his family lived in Moscow. He was involved in social and charitable activity (he was the vice-president of the Charity Society, the president of the Polish Colony and headed the War Victims' Aid Committee). In independent Poland, he was also involved in political life; he served as a senator with four terms in office (twice after running with the Nonpartisan Bloc for Cooperation with the Government, then appointed by the President $)^{1}$. From 1923 until the end of his life, he was president of the church college of the Lutheran-Augsburg Holy Trinity Parish in Warsaw. In the interwar era, he was also a member of the City Council of Warsaw, the Social Welfare Committee, the Committee to Aid the Unemployed and the Merchants' Assembly of the City of Warsaw ${ }^{2}$. He co-founded a bookshop and one of the largest publishing houses in the Second Republic of Poland - Trzaska, Evert, Michalski³. Halina’s mother,

\footnotetext{
${ }^{1}$ In the Sejm of the Republic of Poland, Ludwik Evert worked in the following commissions: administrative and local government, social economy, state debt control, constitutional, treasury and budget, and legal; cf. Biblioteka Sejmowa: https://bs.sejm.gov.pl/F?func=find-b\&request $=000000383$ \&find_code=SYS\&local_base=ARS10 [1 XII 2019].

${ }^{2}$ For more details, cf. Kto byt kim w Drugiej Rzeczypospolitej, ed. J.M. MajChrowski, G. Mazur, K. Stepan, Warszawa 1994, p. 508; H. EverT-Kappesowa, Evert Ludwik Józef (1863-1945), [in:] Polski Słownik Biograficzny, vol. VI, Kraków 1948, p. 323-324.

${ }^{3}$ Cf. M. Pieczonka, Ksiegarnia Wydawnicza Trzaska, Evert, Michalski. Działalność wydawnicza, Kraków 1992.
} 


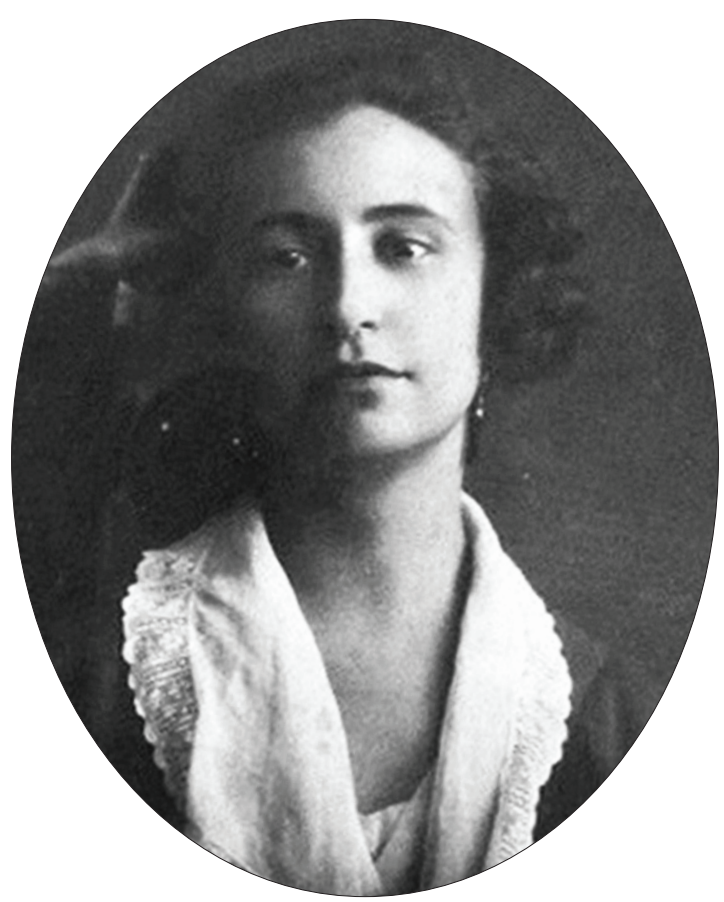

Fig. 1. Halina Evert-Kappesowa in her early youth (photo from Professor W. Ceran's collection).

Pelagia (1867-1950) came from the Pohorecki family, part of the Czaplic, Kierdeja coat of arms ${ }^{4}$. She was the daughter of Konstanty and Apolonia Stanisławska. The Evert family was quite patriarchal. The father was an object of particular reverence, an unachievable ideal and role model for the children; the eldest brother was also exceptionally respected. As the only daughter, Halina had a rather privileged position compared to her brothers, though her parents still had high expectations of her, too.

The future expert in Byzantine studies was most likely born on 27 December $1898^{5}$. In accordance with her wishes and the date in documents from the People's Republic of Poland from the era, most of her biographies state that she was born in Łódź in $1904^{6}$. Apart from Halina, the Everts had three sons: Władysław

\footnotetext{
${ }^{4}$ Polska Encyklopedia Szlachecka, vol. II, ed. S.J. Staryкoń-KASPrZycki, p. 256; vol. X, ed. IDEM, p. 29, Warszawa 1938.

${ }^{5}$ The doubts related to Kappesowa's date of birth have been brought to my attention by doktor Andrzej Koмpa, author of the biography Halina Janina Evert-Kappesowa (Kappes), [in:] Biographical Dictionary of Polish Women Classicists. $20^{\text {th }}$ Century, ed. E. Olechowska, Warsaw 2018, p. 79.

${ }^{6}$ Cf. Akta osobowe Evert-Kappesowa H., Archiwum Uniwersytetu Łódzkiego, ref. 12981; articles by W. Ceran, quoted later in the text; Słownik Biograficzny Historyków Łódzkich, ed. J. Kita, R. SToBIECKI, Łódź 2000, p. 29.
} 


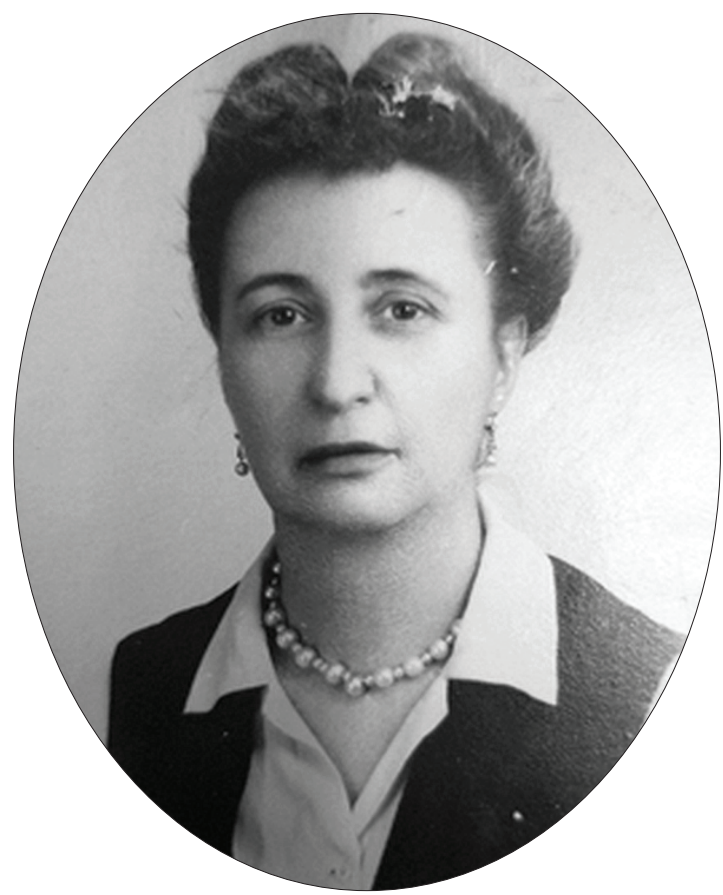

Fig. 2. Halina Evert-Kappesowa - portrait from her personal documents preserved in the Archives of the University of Lodz, sygn. 12981.

(1890-1965; writer, poet, journalist, served in the Anders Army during the war, and, in the People's Republic of Poland, taught Russian at the Warsaw University of Life Sciences); Mieczysław (in the interwar era one of the directors of Bank Zachodni in Warsaw, then a captain of the Polish Army imprisoned in Starobelsk, most probably murdered in Katyń) and Tadeusz (1902-1983; a translator from English $)^{7}$.

As for Kappesowa's birthday, in her personal documents preserved in the Archives of the University of Łódź the information that she was born in Łódź in 1904 is consistently repeated. However, in an earlier job application to "Wolna Wszechnica" (Free University), we have a note written in her hand, with the date December 27, $1900^{\circ}$. In the student index and student records in the Archives of the University of Warsaw, the day of her birth is December 27, 1898, in Moscow $^{9}$. Her student file also contains a document in which another date is given, this

${ }^{7}$ I would like to thank Prof. Ryszard Pohorecki, who kindly provided the information about the Evert-Kappes family from the mother's side.

${ }^{8}$ Cited after M. DĄBrowska, Profesor Halina Evert-Kappesowa i Madame Dupont, PNH 12, 2013, p. 207.

${ }^{9}$ Akta studenckie Kappes H., Archiwum Uniwersytetu Warszawskiego, ref. RP 44616. She was quite reluctant to talk about Moscow as the place where she had spent her childhood. Nevertheless, during 
time $1903^{10}$. Considering what might have been the reason for such discrepancies, we have concluded that she tried to appear slightly younger than her actual age. Hoping to be employed at the University of Warsaw (and the University of Łódź after the Second World War), she decided to subtract several years. In 1936 she was already 38 years old, which was quite an advanced age for an assistant beginning her academic career. The later date of birth was better for her professional prospects.

As far as the place of birth is concerned, after 1945 the historian insisted it was Łódź, thus emphasizing the relationship with the city where her husband came from and where the new university, her future workplace, was located. According to her closest associates, hiding the fact that she was born in Moscow was motivated by the fear that her Polish citizenship might be questioned and, consequently, she might be sent back to the USSR. In fact, there are additional inaccuracies related to Kappesowa's biography.

It is undisputed that the historian's childhood and early youth were spent in Moscow, where she also graduated from secondary school ${ }^{11}$. In 1916, she stayed in Sweden, where for two years she studied English and French at the Ursuline Department near Stockholm ${ }^{12}$. In private conversations, she mentioned the severe nature of Mother Urszula Ledóchowska, who was in charge of the school ${ }^{13}$. After World War I ended, she returned to Poland with her parents. In Warsaw she attended Anna Jakubowska's gimnazjum; however, a lung disease (most probably the beginning of tuberculosis) interrupted her further education ${ }^{14}$. The reason for suspending her education in gimnazjum is not entirely certain, as she mentioned in her later biographies: the difficult material situation and my mother's illness hindered my education, so that I took my Matura [secondary school graduation] exams much later, in $1933^{15}$. It seems unlikely that the Evert family faced financial difficulties in the 1920s. Perhaps in her youth, Halina did not consider formal education to be of much significance, as she had no plans for a future academic career at that point?

In 1922, she took up a job at the American Hoover Mission and the YMCA, which she never mentioned in her official resumes from the communist era.

one of her last conversations with P. Krupczyński, she spoke Russian, symbolically returning to her childhood language.

${ }^{10}$ H. KAPPES, Karta indywidualna dla słuchaczy szkół wyższych, rok 1936/7, [in:] Akta studenckie, ref. RP 44616.

${ }^{11}$ H. KAPPES, Życiorys z 7 września 1932 roku [resume dated September 7 1932], [in:] Akta studenckie, ref. RP 44616.

${ }^{12}$ Ibidem.

${ }^{13}$ Cf. M. DĄвrowska, Profesor Halina Evert-Kappesowa i Madame..., p. 218.

${ }^{14}$ W. Ceran, Prof. dr Halina Evert-Kappesowa i jej dorobek w badaniach nad dziejami Bizancjum, E 75, 1987, p. 229.

${ }^{15}$ H. KAppesowa, Życiorys z marca 1945 r. [resume dated March 1945], [in:] Akta osobowe Evert-Kappesowa... 
Another unknown fact in her biography is a brief time (in the academic year 1922-1923) as a student at the School of Political Sciences at the Consular Faculty. Moreover, only a handful of people knew the details of her first marriage, which lasted just six months and ended in 1923. She officially mentioned it only once in her application to work at the University ${ }^{16}$. Most probably, her parents did not approve of the relationship. In 1928, Halina Glapa-Glapińska née Evert married her second husband, Alfons Kappes, from a German family living in Łódź. Kappes had three brothers, Otto, Aleksander and Pawe ${ }^{17}$. The former two were directors of secondary schools in Łódź, and Alfons became an engineer. The couple, separated by a certain age gap, met in Turkey ${ }^{18}$.

However, before Halina settled there, from 1922-1927 she worked in the Central Military Library in Warsaw, then in the Society for Trade with Turkey (1927-1932) and the Polish-Turkish Chamber (1928-1934) ${ }^{19}$. Her stay in Turkey was a very happy period in her life. Together with her husband, she travelled a lot, got to know the country whose history she would later study. She also took care of the household with the help of Turkish housekeepers. She spoke of those times with great aplomb and delight, with numerous anecdotes and interesting details (for example, about a trained monkey kept in the house, or about the breaking of a hotel ceiling and a bath with two naked Englishmen, etc.). Unfortunately, the Kappeses were not happy for long, as Alfons fell seriously ill and, as part of preparing his wife for independent life in Poland, he encouraged her to pass the Matura exam and study history at the university.

Following her husband's suggestions, Halina began studying at the Faculty of Humanities of the University of Warsaw as a guest student, even before she graduated in 1932. In October 1933, after passing her high school graduation exam at the Lelewel Gimnazjum, she applied to be accepted as a full-time student ${ }^{20}$. Her matriculation as a full-time student took place on December 18, 1933, and she completed her studies on October 26, 1936. Unfortunately, her husband did not live to see that moment: he died on November 29, 1934 at the age of 50.

At the University of Warsaw, she attended classes taught by such scholars as: Marceli Handelsman, Władysław Tomkiewicz (class in the modern history of Eastern Europe), Tadeusz Wałek-Czarnecki (history of the Republic of Rome,

\footnotetext{
${ }^{16}$ H. KAPPES, Życiorys z 7 września 1932 roku, [in:] Akta studenckie, ref. RP 44616.

${ }^{17}$ Otto's grandson is dr hab. Aleksander Kappes, professor at the Department of Commercial Law, to whom I owe the information about the family of the heroine's husband.

${ }^{18}$ Alfonso Kappes was 44 years old (born in 1884) on the wedding day, Halina, 27 (according to a copy of the marriage certificate issued by the Evangelical-Augsburg parish in Warsaw, stored in a students' records). No birth dates were recorded on their marriage certificate, only the age of the spouses, which in the case of Kappesowa suggested yet another date of birth, this time 1901 (!).

${ }^{19}$ Cf. W. Ceran, Profesor dr Halina Evert-Kappesowa. Sylwetka uczonej i pedagoga, RŁ 23, 1975, p. 5; IDEM, Halina Evert-Kappesowa (27 XII 1904 - 10 VI 1985), KH 93, 1986, p. 293-296; IDEM, Prof. dr Halina Evert-Kappesowa i jej dorobek...

${ }^{20}$ Akta studenckie Kappes H., Archiwum Uniwersytetu Warszawskiego, ref. 1789.
} 
Hellenistic world), Stanisław Kętrzyński (auxiliary sciences of history), Jan K. Kochanowski (diplomatic interpretations of Latin texts), Oskar Halecki (the era of Władysław of Varna, the scope and division of the history of Eastern Europe, seminar on the history of the $14^{\text {th }}$ and $15^{\text {th }}$ centuries, the origin of Eastern European countries and nations), Tadeusz Manteuffel (Middle Ages), Majer Bałaban (history of Jews in Europe), Zdzisław Zmigryder-Konopka (Octavian Augustus), Hanna Pohoska (teaching history), Kazimierz Zakrzewski (Christian culture, Greek-Christian culture). Moreover, she attended Władysław Tatarkiewicz’s lectures on aesthetics, logic and praxeology classes taught by Tadeusz Kotarbiński and the psychology of thinking lecture by Władysław Witwicki. She received her Master's degree in history in April $1937^{21}$. Her Master's degree was granted based on her dissertation entitled Poselstwo Camblaka na sobór w Konstancji [Tsamblak's Envoy to the Council of Constance], written under O. Halecki's supervision.

Even before receiving her diploma in 1936, the historian was employed at the University of Warsaw as a junior assistant at the first Department of Byzantine History in Poland, headed by Kazimierz Zakrzewski ${ }^{22}$. In 1938, she replaced Oskar Halecki's assistant (doktor Wanda Maciejewska) at the Department of Eastern European History. She also taught Greek (1938-1939). In 1938, she left for Paris where she studied with the Byzantinists Charles Diehl and Rodolphe Guilland and collected materials for her doctoral dissertation. In the interwar era, she also completed her teaching practice, teaching at the Anna Jakubowska Gimnazjum in Warsaw (1936-1939), and went to London twice to study English for several months.

During the war, Kappesowa was involved in clandestine teaching; in the W. Giżycki and the L. Rudzka gimnazjums, she taught history and English. She was also active in the organization "Freedom and People", (codename: Mirska), where her knowledge of foreign languages was used for radio listening. This is how she remembered that period:

In November, Professor Zakrzewski introduced me to a secret organization where I worked in a group of five, headed by his wife Jadwiga Zakrzewska. I was assigned to radio monitoring and my apartment was used for organizational meetings. That work stopped in 1943, in November or December ${ }^{23}$.

\footnotetext{
${ }^{21}$ Kappesowa Master's diploma features exams in the following areas of knowledge: principles of the historical research method, basic knowledge of auxiliary sciences of history and sources in the history of Poland (good), the history of the Middle Ages in Poland and the world (very good), ancient history (very good), modern and contemporary Polish and world history (very good), general principles of philosophical science (good), in-depth knowledge of the political history of Poland and Rus of the $15^{\text {th }}$ century (very good); cf. H. Kappes, Dyplom magistra filozofii, [in:] Akta studenckie, ref. RP 44616.

${ }^{22}$ Cf. M. Dabrowska, Posłowie. Halina Evert-Kappesowa - uczennica Haleckiego i Zakrzewskiego, [in:] Kazimierz Zakrzewski. Historia i polityka, ed. EADEM, Łódź 2015, p. 309-312.

${ }^{23}$ Curriculum vitae written in March 1945, [in:] Akta osobowe Evert-Kappesowa...
} 
It was during the difficult time of the war (in 1942), at the clandestine university, that Kappesowa obtained her doctorate based on her work Rome et Byzance à l'époque de l'Union de Lyon, 1272-128424. The dissertation was reviewed by Marceli Handelsman and Stanisław Kętrzyński. The doctorate was approved by the Council of the Faculty of Humanities of the University of Warsaw on 16 May 1945 (the doctoral diploma, bearing the grade "very good", was issued on June 28,1945$)^{25}$.

During the Warsaw Uprising, our heroine and her family stayed in Warsaw; later, they were sent to the camp in Pruszków. Eventually, the Everts found shelter with the Radziwiłłs in Nieborów. Małgorzata Dąbrowska wrote about the circumstances of the meeting between $\mathrm{H}$. Evert-Kappesowa and Janusz Radziwiłł:

She stands helpless at the station, probably in Łowicz, because it is known that she had managed to escape from Pruszków. She sees Janusz Radziwiłł as she approaches him. 'Does the duke not recognize me?' she asks hesitantly. Seeing his surprised face, she adds quietly: 'I am Senator Evert's daughter'. Radziwiłł asks about her parents, and when he hears that they are struggling to survive in the countryside, not far away, he invites them to Nieborów, where, while very crowded, a place to stay will be found for them ${ }^{26}$.

In February 1945, Halina comes to Łódź and takes up a job as a teacher at the Maria Konopnicka Gimnazjum and Liceum No. 5. Soon after, her father dies. In 1948, Kappesowa started teaching at the Higher School of Economics. Between 1949 and 1950, she worked as a history lecturer at the Sanitary Training Centre ${ }^{27}$.

At the University of Łódź, she initially taught her assigned classes (lectures on the history of Byzantium, two hours a week) ${ }^{28}$. In October 1950, she was made a senior assistant at the Department of Ancient and Medieval Social History ${ }^{29}$. The head of the aforementioned unit, Marian H. Serejski, provided the following argument for hiring Kappesowa:

She is fully qualified for the senior assistant position [...]. In the face of the multiple teaching duties and the shortage of professional junior academic staff, it seems necessary to allow Dr. Kappesowa to be affiliated with the University and to devote herself fully to applicable work $^{30}$.

\footnotetext{
${ }^{24}$ Akta egzaminacyjne Kappes H., Archiwum Uniwersytetu Warszawskiego, sygn. RP UW W Hum UEM 5496.

${ }^{25}$ H. KAPPESowa, Doctoral degree, [in:] Akta egzaminacyjne...

${ }^{26}$ M. DĄBrowska, Profesor Halina Evert-Kappesowa i Madame..., p. 218-219.

${ }^{27}$ Personal documents from 1950s, [in:] Akta osobowe Evert-Kappesowa...

${ }^{28}$ Cf. Skład osobowy i spis wykładów na rok 1946-1947, Łódź 1947.

${ }^{29}$ The application for work at the University was submitted in April 1950.

${ }^{30}$ M.H. SEREJSKI's assessment from April 1950, [in:] Akta osobowe Evert-Kappesowa...
} 
After being offered the position, the historian taught classes in world history (continued until the mid-1960s) and a monographic lecture on the formation of feudalism in Eastern Europe ${ }^{31}$. It is worth mentioning at this point that the classes she taught at the University of Łódź were different from those of today. They had quite a formal, established order. They started with a protocol from previous classes (a form of recapitulation), then one of the students would read an assigned paper on a given topic, which was followed by a discussion ${ }^{32}$. In the following years, the historian presented a lecture on Eastern Europe during the era of the Crusades and, together with Bogumił Zwolski, supervised a Master's Degree seminar $^{33}$. Index of lectures also includes her Key Issues from the History of Byzantium, Byzantine Sources, Economic Changes in Byzantium and the Balkans in the Seventh-Ninth Centuries, Economic and Political History of Byzantium until 1204 or The Significance of Byzantium in the History of Western Culture ${ }^{34}$.

From 1951 until 1955, Kappesowa worked at the University of Łódź as adiunkt, then as a deputy professor. In 1956, she obtained the academic title of docent (she had first applied for it in 1954, but was denied, as her achievements to date were considered insufficient ${ }^{35}$ ). From 1957 until 1959, she taught at the University of Poznań. She was nominated profesor nadzwyczajny in $1971^{36}$ and retired in 1975. Between 1957 and 1970, at the Institute of History of the University of Łódź, she headed the Department of Byzantine History, which was established on her initiative, as well as the Department of World Ancient and Medieval History $(1966-1975)^{37}$.

Concluding this section of the article, it is worthwhile to briefly outline the scope of Kapessowa's scholarly interests. In terms of chronology and issues covered, her research was quite extensive. As Waldemar Ceran emphasized, it covered practically the entire history of Byzantium from the fourth to the fifteenth century $^{38}$. Małgorzata Dąbrowska adds that her interests ranged from the early (linked to the influence of K. Zakrzewski) to the late Byzantium (O. Halecki's inspirations). The main issue to which Kappesowa devoted many years of her work

${ }^{31}$ Cf. Skład osobowy i spis wykładów na rok 1952-1953, Łódź 1953.

${ }^{32}$ In the 1960s, most of classes at the IH UŁ looked like this.

${ }^{33}$ Cf. Skład osobowy i spis wykładów na rok 1955-1956, Łódź 1956.

${ }^{34}$ Cf. Skład osobowy i spis wykładów na rok 1963-1964, Łódź 1964; 1964-1965, Łódź 1966; 1966-1967, Łódź 1970.

${ }^{35}$ Cf. Akta osobowe Evert-Kappesowa..., p. 138 and Akta osobowe pracowników naukowych, Kappes H., Archiwum Akt Nowych, Zbiór Ministerstwa Szkolnictwa Wyższego w Warszawie, series 26.2, ref. 3193.

${ }^{36}$ Akta profesorskie Evert-Kappesowa H., Archiwum Uniwersytetu Łódzkiego, ref. 140.

${ }^{37}$ Cf. Słownik biograficzny historyków łódzkich..., p. 29-31 (s.v. Evert-Kappesowa Halina); J. KiтA, Halina Evert-Kappesowa (27 grudnia 1904 - 10 czerwca 1985), [in:] Luminarze nauki polskiej w Uniwersytecie Łódzkim. Pro memoria, Łódź 2015, p. 55-58.

${ }^{38}$ W. Ceran, Prof. dr Halina Evert-Kappesowa i jej dorobek..., p. 231-241. 
was the Union of Lyons, a subject on which she wrote the following publications: La société byzantine et l'Union de Lyon (1949), Le clergé byzantin et l'Union de Lyon (1952), La fin de l'Union de Lyon (1956), Stronnictwo antyłacińskie w Konstantynopolu w przeddzień jego upadku [The Anti-Latin Party in Constantinople on the Eve of Its Fall] (1949), Bizancjum a Stolica Apostolska w epoce unii lyon'skiej [Byzantium and the Holy See in the Era of the Union of Lyons] (1983). In the abovementioned works (published mainly in the "Byzantinoslavica" journal), she analyzed the relations between the Emperor Michael VIII Palaiologos and the Holy See in the period preceding the union and during it. She presented the objectives that the emperor expected to achieve, the attitude of the clergy and various groups of Byzantine society to the union, as well as the reasons and circumstances for its collapse.

Another area of Kappesowa's research was the Byzantine-Latin relations before the fall of Constantinople: Stronnictwo antylacińskie w Konstantynopolu w przeddzień jego upadku [The Anti-Latin Party in Constantinople on the Eve of Its Fall] (1949), La tiare ou le turban (1953). In these publications, she analyzed the programs of the pro-Latin and pro-Muslim parties, arguing that the position of the latter - namely that the Turkish rule was a 'lesser evil' than the loss of independence of the Byzantine Church - stemmed not from religious fanaticism but the political realities of the $\mathrm{era}^{39}$.

In line with the expectations of the time, the Łódź-based Byzantine scholar also researched social and economic history. She studied agrarian relations, the social structure of the Byzantine village from the seventh to the ninth centuries and the Slavic colonization in the Balkans. Her most important publications in that field include: Studia nad historia wsi bizantyńskiej w VII-IX w. [Studies of the History of the Byzantine Village in the Seventh-Ninth Century] (1963), Une grande proprieté foncière du VIII s. à Byzance (1963), Recherches sur la colonisation slave à Byzance (1969), Stowianie pod Tesalonika [Slavs under Thessaloniki] (1970), Wielka i drobna własność ziemska w Egipcie w IV-VII w. [Large and Minor Land Properties in Egypt from the Fourth-Seventh Centuries] (1983).

The fourth subject of Kappesowa's research, one she addressed as the last, was the operation of Byzantine social assistance, health care as well as culture and customs from the fourth to the seventh century. This area of interest was represented by works: The Social Rank of a Physician in the Early Byzantine Empire $\left(4^{\text {th }}-7^{\text {th }}\right.$ Centuries AD) (1979) and Historie konstantynopolitańskie [Constantinople's Stories] $(1964)^{40}$.

\footnotetext{
${ }^{39}$ IDEM, Halina Evert-Kappesowa (27 XII 1904 - 10 VI 1985)..., p. 295.

${ }^{40}$ A bibliography of Kappesowa's works was compiled by W. CERAN in "Rocznik Łódzki" 23, 1975, p. 15-21 and the journal "Eos" 75, 1987, p. 245-250.
} 
In addition to her research, Kappesowa was involved in activities aimed at popularizing and encouraging interest in the history of Byzantium in Poland ${ }^{41}$. For example, the work dedicated to K. Zakrzewski, entitled Historie Konstantynopolitańskie [Constantinople's Stories] (1964), served to popularize Byzantium-related issues. This publication consisted of essays aimed at introducing the Polish reader to the culture of the Byzantine state, its peculiarities and its everyday life $e^{42}$. Kappesowa also introduced the achievements of Byzantine studies and reviewed the works of Polish, Soviet, English, French and German historians ${ }^{43}$. She initiated a number of translations; one of her achievements was the 1967 publication of the Polish translation of George Ostrogorsky's synthesis History of the Byzantine State ${ }^{44}$. In the preface to the Polish edition, Ostrogorski stressed, I am glad that work on the translation was undertaken by such an outstanding specialist as docent $d r \mathrm{H}$. Evert-Kappesowa, as this is a guarantee of the quality of the outcome ${ }^{45}$.

It is worth mentioning that in the aforementioned volume the Łódź-based historian outlined the state of Polish research on the history of Byzantium todate. According to her observation,

Byzantine research in Poland has been mostly casual and random. The history of Byzantium was considered attention-worthy as long as it was associated with the examined problem or could shed light thereon. Classical philologists, therefore, have attempted to learn and establish how and in what way the influence of antiquity on Byzantine speakers and writers was expressed. Historians of the Polish Middle Ages have been interested in Byzantium almost exclusively from the point of view of the Greek church's relations with Rus. Researchers of the history of the Slavic region have drawn relevant information from Byzantine

\footnotetext{
${ }^{41}$ The Byzantine issues were popularized by the entries she compiled for Słownik Starożytności Słowiańskich. Encyklopedyczny zarys kultury Słowian od czasów najdawniejszych, ed. W. KowALENKo, G. LABUdA, T. LeHR-Sp£AWIŃsKi, vol. I, Wrocław 1961; vol. II, Wrocław 1964.

${ }^{42}$ H. Evert-Kappesowa, Wstęp, [in:] Eadem, Historie Konstantynopolitańskie, Warszawa 1964, p. 6. The book consisted of six essays devoted to: Theodora, Philaret the Merciful, Theodore of Stoudios/the Stoudite, Ptochoprodromos/the poor Prodromos, doctors in Byzantium and the capital of the Byzantine state. In addition, the volume was provided with an introduction and bibliographic guidelines.

${ }^{43}$ As Ceran noted, in the above-mentioned publications she not only presented other people's achievements, but also expressed her own views and findings, which allowed her to actively participate in the international discussion on key issues in the history of Byzantium, Prof. dr Halina Evert-Kappesowa i jej dorobek..., p. 240.

${ }^{44}$ The Polish-language version of the work, which according to specialists was the best introduction to Byzantine issues, was the sixth after German, French, English, Serbo-Croatian and Slovakian. It was done by a team of several Łódź-based Byzantine specialists under the direction of Kappesowa, based on the third (supplemented) German edition (Geschichte des Byzantinischen Staates, München 1963).

${ }^{45}$ G. Ostrogorski, Przedmowa autora do wydania polskiego, [in:] IDEm, Dzieje Bizancjum, trans. supervised by H. Evert-Kappesowa, Warszawa 1967, p. 5.
} 
chroniclers. Therefore, some sections and certain periods of Byzantine history have been investigated with a great deal of accuracy, while others remain practically untouched ${ }^{46}$.

Kappesowa also stressed that before Ostrogorski's work was translated, there had only been one historiography textbook in Polish (Dzieje Byzancjum. Wielka historia powszechna [The History of Byzantium. The Great History of the World] by K. Zakrzewski), which did not cover the time after 1204, and as such it did not include the final phase of the state's existence.

\footnotetext{
Despite its undeniable advantages, we will not find answers there [in Zakrzewski's textbook - JK] to many questions about economic, political and social history, which today we ask of works of such kind. Hence, the growing need to provide our scholarly literature with a book that would capture the history of Byzantium in its various aspects, from the beginning of the state's existence until its end ${ }^{47}$.
}

By the way, our heroine very aptly characterized the specific character of research and the problems that Polish Byzantinists had to face. She stressed that the development of this sub-discipline was hampered by a lack of sources and access to literature (access to new source publications published in Western Europe was limited, and Polish scholars had hardly any opportunity to carry out queries abroad). Another problem was the required knowledge of at least two classical languages and, preferably, several foreign ones, which was an obstacle for many of the students of our universities, who generally do not have such qualifications and thus, despite their interest, have to give up Byzantine studies ${ }^{48}$. As she explained, those were the reasons for the limited interest in the history of Byzantium in the post-war era, emphasizing at the same time the determination, resolve and fortitude of all those who, despite the hindrances, decided to pursue this field of study.

Concluding the subject of $\mathrm{H}$. Evert-Kappesowa's scholarly accomplishments, it is worth noting that despite the isolation resulting from life behind the Iron Curtain, following the Thaw (after 1956), she participated in international scholarly life. She carried out research projects and visited a number of places abroad, also behind the Iron Curtain: Ohrid (1961), Strasbourg (1969), Dumbarton Oaks (1971-1972), Paris (1973) and Athens (1976). She also endeavored to popularize

${ }^{46}$ H. Evert-Kappesowa, Bizantynistyka w Polsce, [in:] G. Ostrogorski, Dzieje Byzancjum ..., p. 45. In Historie Konstantynopolitańskie she emphasized that works devoted exclusively to Byzantine issues were extremely rare in Polish scholarly literature. The real breakthrough was the establishment of the Department of the History of Byzantium at the University of Warsaw, whose research, however, was interrupted by the war. The death of K. Zakrzewski, who was murdered by the Nazis, was an irretrievable loss.

${ }^{47}$ H. Evert-Kappesowa, Wstęp..., p. 7.

${ }^{48}$ Eadem, Bizantynistyka $w$ Polsce... 
Byzantine issues in the field of university didactics. In 1957-1970, on her initiative and under her direction, the Byzantine History Department, the only such unit in Poland at that time, was active at the University.

Kappesowa was also a member of international scholarly societies, such as the Comité National Polonais or the Committee of Antiquity Sciences of the Polish Academy of Sciences; she was a member of Polish Historical Society (PTH) and Łódź Scholarly Society (ŁTN). She participated in international conventions and conferences, including the Byzantine Congress in Prague (1957), the congress in Weimar (1961), the $12^{\text {th }}$ International Byzantine Congress in Ohrid (1961), the International Byzantine Congress in Oxford (1966) and the International Byzantine Congress in Athens (1976). She spoke at Byzantium-themed symposia in Strasbourg $(1969,1973)$, and Paris (1973). She gave lectures at the universities in Toulouse and Bochum and had her works published in prestigious journals, such as "Byzantinoslavica", "Meander", "Paleologia", "Vizantijskij Vremiennik", "Przegląd Historyczny" and "Kwartalnik Historyczny".

She was also highly accomplished in the field of didactics. She was involved in school textbooks on ancient history ${ }^{49}$. She supervised three doctoral dissertations at the University of Łódź: Waldemar Ceran (1967), Piotr Krupczyński (1977), Małgorzata Dąbrowska (1985) and fourteen master’s theses ${ }^{50}$.

\section{Academic advancement under the communist regime}

The beginning of H. Evert-Kappesowa's scholarly career was not typical. She decided to pursue it quite late; most likely, when planning her life, she was restricted by the social class from which she hailed. Representatives of landowning families, as well as daughters of the political and financial elites of the Second Polish Republic, most often associated their future with an "appropriate" marriage. Had it not been for the premature death of Alfons Kappes, perhaps our heroine's life would have turned out completely different.

\footnotetext{
${ }^{49}$ H. Kappesowa, B. Zwolski, Historia starożytna dla klasy VIII, Warszawa 1958, p. 359 (7 editions, including: 1959, 1960, 1961, 1962, 1963, 1965). The handbook was well received from the point of view of the attractiveness of the lecture and the use of the methods of illustrative teaching. It is evident that the authors and the publisher put considerable effort into making the material as rich as possible, despite the modest technical means available to our printing industry, showing various aspects of ancient life; A. KraWczuK, Uwagi metodyczne o podręczniku H. Evert-Kappesowej i B. Zwolskiego, Historia starożytna dla klasy VIII, PZWS Warszawa 1960, WHi 4.1, 1961, p. 45.

${ }^{50}$ She supervised the theses of: Waldemar Ceran (1960), Stanisław Wiśniewski (1960), Adam Chodakowski (1962), Zofia Gaszyńska (1964), Marian Wiktorowski (1965), Andrzej Dyło (1967), Stefan Kwaśniak (1968), Urszula Krupczyńska (1968), Piotr Krupczyński (1968), Eleonora Trzcińska (1969), Jerzy Kotowski (1969), Renata Bolanowska (1974), Paweł Dzieciński (1977), Jacek Kluczkowski (1981).
} 
However, luckily for Polish Byzantine studies, Kappesowa's professional experience, her extended stay in the Middle East and her excellent knowledge of foreign languages sparked her interest in the history of Byzantium. However, the historian, who would later contribute to laying the foundations of post-war Polish Byzantine studies, did not have an easy start in communist Poland. As the daughter of a pre-war industrialist, senator and publisher, she represented the social class condemned to marginalization in the new system. The safe and familiar world of Evert-Kappesowa collapsed in September 1939. Having survived the war, she had to adapt to the new reality. Her stubbornness, determination and high intellectual competence undoubtedly facilitated the adaptation in the socialist state.

The forty-seven-year-old widow, responsible for the care of her elderly, sick mother, moved to Łódź (her husband's home city), and into a modest one-bedroom apartment ${ }^{51}$. From the very beginning, she tried to secure a position at the university, which she did not manage until 1950. As Małgorzata Dąbrowska argues, applying for employment and then working at the University of Łódź, she was repeatedly forced to "camouflage herself". In personal documents, she omitted information about her father's service in the Senate, and described his profession as follows: "bookseller, employee of K. Scheibler's company"52. Even in 1948, compiling the entry dedicated to Ludwik Evert for the PSB [Polish Biographical Dictionary], she was very cautious in her characterization of his political activity, stressing his charity efforts instead: supporting workers, merchants, war victims, the unemployed, etc. Characterizing her own social and political activity from the interwar period, she emphasized that she had not belonged to any political parties, but had been only involved in scholarly and social organizations (in the 1951 questionnaire, she mentioned the membership in the Polish Teachers' Union, ZNP). In the People's Republic of Poland, she was a member of the Women's League and the Society of Polish-Soviet Friendship. Justifying her lack of political involvement, she wrote: Conditions at home (the paralysis my mother suffered) prevented me from active participation. I do not belong to any political organizations $^{53}$. When asked whether her relatives had been arrested, she confirmed it: $m y$ brother was arrested in 1948. The reason was not disclosed; he was soon released without any trial. Father was arrested for refusing to sign the Volksliste, but he was released because of his old age ${ }^{54}$. Characterizing family relations, she mentioned her brother Mieczysław, who had not survived the war, leaving aside information about his murder by the Soviets.

\footnotetext{
${ }^{51}$ Professor R. Pohorecki claims that he visited Evert-Kappesowa and her mother in their apartment on Obrońców Stalingradu Street (today's Legionów). Most probably, after her mother's death, Kappesowa moved to 19 Stycznia Street (today's Karola Anstadta Street).

${ }_{52}$ Personnel survey, May 1950, [in:] Akta osobowe Evert-Kappesowa...

${ }^{53}$ Ibidem.

${ }^{54}$ Ibidem.
} 
At this point, it is impossible to avoid the question of whether a person with such a family history could advance within the structures of academia in the People's Republic of Poland? After all, universities did not operate in a vacuum and ideological issues had a significant impact on both the research and staff employment policy. Looking at our heroine's career through the prism of the records in the Archives of the University of Łódź, one can conclude that her subsequent promotions were excessively delayed. As has been already signaled, H. Kappesowa applied for the docent title for the first time in 1954. A year later (in April 1955), the Central Selection Committee sent a letter that read: According to the Committee's assessment, the achievements to date do not meet the requirements set for the academic title of an independent researcher ${ }^{55}$. On April 25, the Senate of the University of Łódź requested that the application be reconsidered (the letter stated that the case also concerned doktor K. Kąkol, doktor Z. Izdebski, doktor B. Zwolski and doktor W. Ostrowski, eight persons in total). In accordance with the procedure, in Kappesowa's case, a second application had to be submitted, which she did on May 31, 1955. The application was accompanied by a list of publications, which consisted of eight articles (including five in French), eleven reviews (of which ten concerned foreign literature) and two popular science works. In an assessment of Kappesowa's achievements written in June 1955, Gerard Labuda stressed:

Evaluating all of doktor Kappesowa's scholarly output, we can state that the author, both in her research and popular science works, as well as in a number of critical reviews from various fields of Byzantine history, shows excellent philological background and complete mastery of the difficult research methodology required in Byzantine studies. Thus, future adepts of Polish Byzantinology could be trained under her guidance. Taking into account the sad state of our Byzantine studies, it is necessary to make every effort to ensure that its frail fire, supported at the University of Łódź by profesor Serejski and doktor Kappesowa, can be better stirred. Taking into account doktor Kappesowa's research achievements to date, her great enthusiasm for work even under the most difficult circumstances, almost without her own library resources, also with a view to undertaking new, creative scholarly issues, I simply consider it a necessity to grant her the title of docent, stabilizing her as an independent researcher and enabling her to organize her own unit. The existence of such an institution in Poland is not only a matter of honor for our science [emphasis mine - JK] [...] but it is necessary for the development of our own historiography, because the history of Byzantium is so closely associated with the past of Slavic states that there can be no decent Slavic studies without Byzantine studies ${ }^{56}$.

As a result of the repeated application and Labuda's assessment, the title of docent was awarded to Kappesowa on October 1, 1956.

The subsequent promotion of the historian was also a long process. The procedure for awarding her the title of profesor nadzwyczajny began on June 28, 1962. In accordance with the procedure, questionnaires were sent to the leading research

\footnotetext{
${ }^{55}$ Ibidem.

${ }^{56}$ G. LabUdA's opinion on H. Kappesowa, [in:] Akta osobowe Evert-Kappesowa...
} 
centers (UW, UJ, UAM, UMCS, UMK, Bolesław Bierut University) with a request to evaluate her achievements. In response, Tadeusz Manteuffel wrote that the request was premature:

Since obtaining the title of docent in 1956, her writing output has consisted of four small articles and eight reviews. Five items including two books have been submitted for printing. ${ }^{57}$

\section{M.H. Serejski gave a different answer to the same question:}

Taking into account docent Kappesowa's recently printed work on the Byzantine village, her good knowledge of literature and latest academic endeavors in the field of Byzantine studies, both in the East and West, all her scholarly and popular science achievements, as well as her teaching experience (before the war she had served as assistant to Prof. K. Zakrzewski), I think she could be appointed profesor nadzwyczajny ${ }^{58}$.

Having read the manuscript of the book mentioned by Serejski (Studia nad historia wsi bizantyńskiej w VII-IX w.) Tadeusz Manteuffel amended his initial assessment. Unfortunately, the problems with the application continued. The Ministry evidently delayed their reply. Dean Bogumił Zwolski intervened, sending the following letter to the Rector of the University of Łódź:

The Dean's Office of the Faculty of Philosophy and History asks the Rector to kindly explain the reasons why the motion of the Faculty Council, supported unanimously by the resolution of the Senate of February 24, 1964 on granting docent Halina Kappesowa the title of profesor nadzwyczajny has not yet been either approved or denied by the Ministry. [...]. In the meantime, docent doktor Halina Kappesowa has expanded her scholarly output, and she supervised her assistant's doctoral dissertation, which has already been published ${ }^{59}$.

Additionally, Zwolski stressed the uniqueness of Kappesowa's research:

Researchers who devote themselves to such issues are doomed to work in seclusion, not just without advice or assistance, but also without sources and studies. They have to be collected from all the libraries of the whole country and large gaps have to be reckoned with ${ }^{60}$.

In 1970, Kappesowa's documentation was supplemented with a new list of publications: one monograph, three studies and treatises, six scholarly articles, fourteen occasional articles, reviews, polemical pieces and contributions, two popularscientific works, one source text, one edited work, two works submitted for printing

${ }^{57}$ T. MANTEUffel, Odpowiedź na ankietę ws. powołania na stanowisko profesora nadzwyczajnego, [in:] Akta profesorskie Evert-Kappesowa H., Archiwum...

${ }^{58}$ M.H. SEREJSKI, Odpowiedź na ankietę w sprawie powołania na stanowisko profesora nadzwyczajnego, [in:] Akta profesorskie Evert-Kappesowa H., Archiwum...

${ }^{59}$ Letter from the Dean of the Faculty of Philosophy and History B. Zwolski to the Rector of the University of Łódź, [in:] Akta profesorskie Evert-Kappesowa H., Archiwum...

${ }^{60}$ Ibidem. 
and entries for the Słownik Starożytności Słowiańskich [Dictionary of Slavic Antiquities]. A total of nineteen publications from the time she was awarded the title of docent. This time, the output was considered sufficient and in 1971 (almost ten years after the application had been submitted), the State Council granted Kappesowa the title of profesor nadzwyczajny. Of course, it can be assumed with a high degree of likelihood that with regard to a person with a different name, political attitude and field of interest, the ministry would have been less inclined to delay the process. However, it is difficult to prove that the blocking of the promotion was deliberate since our heroine's scientific achievements were small in quantitative terms. The reviews unanimously emphasized the historian's language and professional competence, excellent knowledge of primary sources, enthusiasm for work and teaching experience dating back to the interwar period. At the same time, they stressed the specific character of Byzantine research; the lack of mentors, the need to develop new research methods, and difficulties in accessing sources. The sub-discipline, which set such high requirements, also involved the need to search for talented students whose dissertations could be supervised. As a result of the above, Byzantine studies were not in the mainstream of historical research during the communist era.

One more thing should be mentioned, namely, the book which would play a significant role in the heroine's professorial advancement - Studia nad historia wsi byzantyńskiej w VII-IX wieku (Łódź 1963). It received mixed reviews. The Byzantine scholar, who had so far specialized in the history of the Union of Lyons and who preferred political and cultural history, was "forced" to take up issues of social and economic history due to ideological pressure. As she herself mentioned, she was not particularly confident in that area, but nevertheless, she undertook the "suggested" research subject. She focused on the Byzantine village at a time considered critical (and groundbreaking) in the history of the Roman Empire. In terms of the territorial scope of the work, she mainly covered Egypt and the Balkans - economically and strategically important provinces. As she herself admitted, a comprehensive economic history of Byzantium should take into consideration the local characteristics and natural conditions of each district of the country. Unfortunately, the scarce and fragmented source data made this impossible. In the introduction to her book, Kappesowa emphasized that

the structure of this work was in a way determined by research complications and the condition of the sources. Egypt kept more of my attention longer, because until the mid-seventh century it played an important role in the economy of Byzantium, and its facilities were probably to some extent a model for other provinces, but also because we have the greatest amount of material available for its socio-economic history ${ }^{61}$.

${ }^{61}$ H. Kappesowa, Słowo wstępne, [in:] Studia nad historiq wsi bizantyńskiej w VII-IX wieku, Łódź 1963, p. 14. 
Syria and Palestine did not, in her opinion, play any significant role in the history of the Byzantine village and there was not enough data to be used. The author divided the obtained materials into the following groups: accounts, chronicles, documents (such as the Imperial Chancellery Register, Records of the Constantinople's Patriarchate, etc.), legal sources (such as the Code of Justinian, Farmer's Law, etc.), hagiographic sources and literature. As for materials of Arabic provenance, she only had access to them indirectly and in fragments. She pointed out that she had had to search for information in a variety of places, assembling a narrative from crumbs: together they made up a structure that was incomplete and very flawed ${ }^{62}$. However, for the economic history of Byzantium to be written at some point in the future, a number of minor works must pave the way.

Naturally, a first attempt in this field will be far from perfect, including the volume in question. Perhaps, however, despite all its faults, this monograph may be of certain use, all the more so as it is one of the first works strictly in the field of Byzantine studies to be published in Polish and for Polish readers ${ }^{63}$.

Despite those reservations, in 1964, the young Warsaw-based historians Tadeusz Wasilewski and Ewa Wipszycka published a review in "Przegląd Historyczny", in which they questioned the chronological framework adopted by the author ${ }^{64}$. They argued that the analyses of the Early Byzantine period be included, as, in their opinion, it was in that era that the described phenomena had originated. Additionally, the late ninth century, which marked the end of Kappesowa's narrative, should be classified as a part of the subsequent era. However, the reviewers found Chapter I, devoted to large and minor land property in Egypt, to be particularly problematic. The Warsaw-based historians stated that the author had not carried out independent source research in that regard; she relied only on previous findings. In addition, they demonstrated her ignorance of the latest secondary sources, which, in their view, resulted in a number of simplifications and errors. They also pointed out that Kappesowa had put too much faith in the data found in hagiographic sources ${ }^{65}$. They indicated the need to define the difference between a town and a village in the discussed period. As far as further parts of the volume were concerned, the reviewers voiced their reservations regarding the author's omission of the peaceful infiltration of barbaric peoples into the borders of the Empire and her failure to take into account the relations between the Slavs and the population they conquered. In the conclusion of their review, Wasilewski

\footnotetext{
${ }^{62}$ Ibidem, p. 15.

${ }^{63}$ Ibidem, p. 16.

${ }^{64}$ A short note by Zofia Podwińska devoted to this work was published in "Kwartalnik Historii Kultury Materialnej" 12.1, 1964, p. 733.

${ }^{65}$ T. WAsIlewsKi, E. WipszYcKa, [rec.:] Studia nad historiq wsi bizantyńskiej w VII-IX wieku, Halina Evert-Kappesowa, Łódź 1963 - PH 55.4, 1963, p. 670.
} 
and Wipszycka stated that Kappesowa's book did not expand the knowledge about the Byzantine village and did not enrich the scholarly discussion with new arguments and findings. It is limited to the presentation of the extensive secondary sources and the historiographic concepts of the Russian and Soviet Byzantine school ${ }^{66}$.

In response to the critical review, Evert-Kappesowa sent a letter to the editors of "Przegląd Historyczny" in defense of her work, thus starting a discussion with the reviewers, which continued in the journal in 1965. The scholar pointed out with regret that the reviewers of the work had failed and/or not wanted to notice that it was not an attempt at an exhaustive presentation of the history of the Byzantine village, but only studies on the history of the village that consisted of three essays. She reiterated that the preserved material had only allowed for the reconstruction of a fragmentary image that never pretended to be the history of a village in Byzantium during the examined period ${ }^{67}$. The aim of including Egypt in the narrative would supplement the established material with new data, taken from hagiographies, rent contracts, published, but not yet analyzed ${ }^{68}$. As for the accusation of failing to present the attitude of Slavic invaders towards the indigenous people, Kappesowa wrote:

It is regrettable that the reviewers failed to indicate where to obtain the necessary data to reconstruct such an image. None of the sources we know today provide such material, except for a few scarce and rare references ${ }^{69}$.

As the historian concluded,

It does not mean that I reject en bloc the accusations made against me. I think, for example, that the third essay would have been significantly better if it had presented the growing diversity between the provincial and capital aristocracy; the title would have reflected the content of the work better if it was Studia nad historia wsi w Bizancjum w VII-IX wieku [Studies on the History of the Village in Byzantium in the Seventh-Ninth Century] (1963). [...]. Criticism, if it is to be serious, should be as impartial as possible and based on factual arguments. Such arguments are hardly found in the review, and what I found there instead, is a very bold - for such young Byzantine scholars - and unsubstantiated disqualification of the work, a list of all its allegedly missing elements (and which for the most part cannot or should not have been included) and a complete omission of the author's contribution ${ }^{70}$.

In response to that letter, Wipszycka and Wasielewski upheld most of their accusations. In their opinion, Kappesowa had failed to prove convincingly her original contribution to the research on the Byzantine village. They also maintained the view that in Chapter III there are no new statements or new approach to the cited

\footnotetext{
${ }^{66}$ Ibidem, p. 673.

${ }^{67}$ H. Evert-Kappesowa, List do Redakcji, PH 56.2, 1965, p. 350.

${ }^{68}$ Ibidem.

${ }^{69}$ Ibidem, p. 351.

${ }^{70}$ Ibidem, p. 352.
} 
works ${ }^{71}$. In hindsight, it is difficult to reconstruct the then-state of knowledge and the preservation of sources, thus clearly determining the validity (or lack thereof) of the comments made by the reviewers. Undoubtedly, the young Warsaw-based historians were well acquainted with the sources and the latest literature on the subject; they travelled the world, carried out queries and were highly competent. Ewa Wipszycka was an expert in research on the history of Egypt, while Tadeusz Wasilewski dealt with the history of Slavs and Byzantium. Familiar with the most recent literature, they demonstrated Kappesowa's shortcomings in that regard. As the Byzantinists admit, the author's readings of that time were monumental, but classical. Confronted with the young researchers, Kappesowa did not fare too well and she was aware of her book's weakness. However, her contribution to the attempt to describe the economic history of Byzantium for the Polish reader cannot be denied $^{72}$. The requirements for career advancement and ideological pressure determined the choice of the topic, which was difficult to achieve for the Łódź-based scholar in the 1950s, as she had not yet gone abroad to carry out queries at that time. Kappesowa was very upset about her younger colleagues' critical review. She was known for holding grudges so she meticulously listed all the flaws she found in T. Wasilewski's 1972 book Bizancjum i Słowianie w IX w. Studia $z$ dziejów stosunków politycznych i kulturalnych [Byzantium and Slavs. Studies in the History of Political and Cultural Relations $]^{73}$.

To conclude the evaluation of the researcher's achievements, it is worth quoting the opinion of W. Ceran, who admitted that Kappesowa's works, while primarily small studies, are nevertheless very insightful, erudite, presenting the problem in depth. [...] They solve many controversial problems in Byzantinology or illuminate them to the extent that current knowledge allows ${ }^{74}$. There were no large syntheses or extensive monographs in her oeuvre. She excelled at analytical work, which, while written in foreign languages (mainly French), became part of the international scholarly discourse. Such achievements cannot be easily and unambiguously assessed. In quantitative terms, it was not an impressive output, but specialists have recognized its value. The passage of time and the development of the discipline have shown the unquestionable merits of Kappesowa, a researcher who laid a solid foundation for later Byzantine research.

Halina Evert-Kappesowa died on June 10, 1985. She was buried in the Lutheran-Augsburg cemetery in Warsaw in the Evert family tomb ${ }^{75}$.

\footnotetext{
${ }^{71}$ Cf. E. Wipszycka, T. WAsilewski, Listy do Redakcji, PH 56.2, 1965, p. 353-355.

${ }^{72}$ I refer here to the opinion of Professor Małgorzata DĄBROWSKA expressed in correspondence on this subject.

${ }^{73}$ Cf. H. Evert-Kappesowa, [rec.:] Tadeusz Wasilewski, Słowianie w IX w. Studia $z$ dziejów stosunków politycznych i kulturalnych, Państwowe Wydawnictwo Naukowe, Warszawa 1972, p. 234, 2 cartes - "Byzantinoslavica. Revue internationale des études byzantines" 35.1, 1974, p. 57-60.

${ }^{74}$ W. Ceran, Prof. Halina Evert-Kappesowa, GRo 2 July 1985, no. 152, p. 4.

${ }^{75}$ The Evert family tomb is located in sector Al24, row 1, grave number 26.
} 


\section{Bibliography}

\section{Primary Sources}

Akta egzaminacyjne Kappes H., Archiwum Uniwersytetu Warszawskiego, sygn. RP UW W Hum UEM 5496.

Akta osobowe Evert-Kappesowa H., Archiwum Uniwersytetu Łódzkiego, ref. 12981.

Akta osobowe pracowników naukowych, Kappes H., Archiwum Akt Nowych, Zbiór Ministerstwa Szkolnictwa Wyższego w Warszawie, series 26.2, ref. 3193.

Akta profesorskie Evert-Kappesowa H., Archiwum Uniwersytetu Łódzkiego, ref. 140.

Akta studenckie Kappes H., Archiwum Uniwersytetu Warszawskiego, ref. 1789.

Akta studenckie Kappes H., Archiwum Uniwersytetu Warszawskiego, ref. RP 44616.

Evert-Kappesowa H., Bizantynistyka w Polsce, [in:] G. Ostrogorski, Dzieje Bizancjum, trans. supervised by H. Evert-Kappesowa, Warszawa 1967.

Evert-Kappesowa H., Evert Ludwik Józef (1863-1945), [in:] Polski Słownik Biograficzny, vol. VI, Kraków 1948, p. 323-324.

Evert-Kappesowa H., Historie Konstantynopolitańskie, Warszawa 1964.

Evert-Kappesowa H., List do Redakcji, "Przegląd Historyczny” 56.2, 1965, p. 350-352.

Evert-Kappesowa H., [rec.:] Tadeusz Wasilewski, Słowianie w IX w. Studia z dziejów stosunków politycznych i kulturalnych, Państwowe Wydawnictwo Naukowe, Warszawa 1972, p. 234, 2 cartes - "Byzantinoslavica. Revue internationale des études byzantines" 35.1, 1974, p. 57-60.

Evert-Kappesowa H., Wstęp, [in:] G. Ostrogorski, Dzieje Bizancjum, trans. supervised by H. Evert-Kappesowa, Warszawa 1967.

Kappesowa H., Studia nad historiq wsi bizantyńskiej w VII-IX wieku, Łódź 1963.

Kappesowa H., Zwolski B., Historia starożytna dla klasy VIII, Warszawa 1958.

Słownik Starożytności Słowiańskich. Encyklopedyczny zarys kultury Słowian od czasów najdawniejszych, ed. W. Kowalenko, G. Labuda, T. Lehr-SpŁaWiński, vol. I, Wrocław 1961; vol. II, Wrocław 1964.

\section{Secondary Literature}

Biblioteka Sejmowa, https://bs.sejm.gov.pl/F?func=find-b\&request=000000383\&find_code=SYS\&local _base $=$ ARS10

Ceran W., Halina Evert-Kappesowa (27 XII 1904 - 10 VI 1985), "Kwartalnik Historyczny" 93, 1986, p. 293-296.

Ceran W., Prof. dr Halina Evert-Kappesowa i jej dorobek w badaniach nad dziejami Bizancjum, "Eos" 75,1987, p. 229-241.

Ceran W., Prof. Halina Evert-Kappesowa, “Głos Robotniczy” 2 July 1985, no. 152, p. 4.

Ceran W., Profesor dr Halina Evert-Kappesowa. Sylwetka uczonej i pedagoga, "Rocznik Łódzki" 23, 1975, p. 5-14.

DąBrowska M., Posłowie. Halina Evert-Kappesowa - uczennica Haleckiego i Zakrzewskiego, [in:] Kazimierz Zakrzewski. Historia i polityka, ed. M. DĄвrowska, Łódź 2015, p. 309-313.

Dąвrowska M., Profesor Halina Evert-Kappesowa i Madame Dupont, "Przegląd Nauk Historycznych" 12, 2013, p. 193-219. 
KITA J., Halina Evert-Kappesowa (27 grudnia 1904 - 10 czerwca 1985), [in:] Luminarze nauki polskiej w Uniwersytecie Łódzkim. Pro memoria, Łódź 2015, p. 55-58.

Koмpa A., Halina Janina Evert-Kappesowa (Kappes), [in:] Biographical Dictionary of Polish Women Classicists. $20^{\text {th }}$ Century, ed. E. OlechowsKa, Warsaw 2018, p. 79.

Krawczuk A., Uwagi metodyczne o podręczniku H. Evert-Kappesowej i B. Zwolskiego, Historia starożytna dla klasy VIII, PZWS Warszawa 1960, "Wiadomości Historyczne" 4.1, 1961, p. 43-45.

Kto był kim w Drugiej Rzeczypospolitej, ed. J.M. Majchrowski, G. Mazur, K. Stepan, Warszawa 1994.

Ostrogorski G., Przedmowa autora do wydania polskiego, [in:] G. Ostrogorski, Dzieje Bizancjum, trans. supervised by H. Evert-Kappesowa, Warszawa 1967.

Pieczonka M., Księgarnia Wydawnicza Trzaska, Evert, Michalski. Działalność wydawnicza, Kraków 1992.

Polska Encyklopedia Szlachecka, vol. II; vol. X, ed. S.J. Stary Koń-KasPrzycki, Warszawa 1938.

Skład osobowy i spis wykładów na rok 1946-1947, Łódź 1947; 1952-1953, Łódź 1953; 1955-1956, Łódź 1956; 1963-1964, Łódź 1964; 1964-1965, Łódź 1966; 1966-1967, Łódź 1970.

Słownik Biograficzny Historyków Łódzkich, ed. J. KiтA, R. Sтовіескі, Łódź 2000.

Wasilewski T., Wipszycka E., Listy do Redakcji, "Przegląd Historyczny” 56.2, 1965, p. 353-355.

Wasilewski T., Wipszycka E., [rec.:] Studia nad historia wsi bizantyńskiej w VII-IX wieku, Halina Evert-Kappesowa, Łódź 1963 - "Przegląd Historyczny" 55.4, 1963, p. 669-673.

\begin{abstract}
This article aims to expand information on the life and academic career of a historian from Łódź, the co-founder of Polish post-war Byzantine studies - Halina Evert-Kappesowa. Based on student files preserved at the University of Warsaw, as well as employee and promotion records in the Archives of the University of Łódź, the author has established facts such as the date and place of Kappesowa's birthday, subsequent stages of education and reasons for her delayed promotions. She has also addressed Evert-Kappesowa's achievements and their reception. This paper provides vital additions to the debate on the contribution of female historians to the development of Polish history.

The text consists of two parts; the first is devoted to the biography of the heroine and her research interests. The second concerns the course of her scientific career.
\end{abstract}

Keywords: Halina Evert-Kappesowa, biography, scientific career, history of historiography, Byzantine studies, PRL

Jolanta Kolbuszewska

University of Lodz Faculty of Philosophy and History Institute of History Department of History of Historiography and Auxiliary Sciences of History

ul. Kamińskiego 27a

90-219 Łódź, Polska/Poland jolanta.kolbuszewska@uni.lodz.pl 